\title{
Czyżby przedwczesny krzyk sowy Minerwy? 0 renesansie syberyjskiego szamanizmu
}

\begin{abstract}
In this study, I refer to the metaphor of the cry of Minerva's owl, which was supposed to herald the twilight of a given phenomenon into the classic scientific descriptions of Siberian shamanism, which was treated by many scientists as part of the phenomenon "universal" for the history of the religion of humanity, and at the same time belonging only to the past. I am analysing the concepts of Mircea Eliade and Andrzej Wierciński in the context of my own field research on the Renaissance of Siberian shamanism. I propose a reflection on the usefulness and limitations of classical models of shamanism for studying contemporary religions of ethnic peoples traditionally considered to be shamanic. Certainly many researchers have become interested in issues related to shamanism thanks to the suggestive descriptions of the classics. The classic model of shamanism is therefore useful as a free frame of intellectual inspiration. Their usefulness decreases abruptly when we treat them as a summary of knowledge about shamanism. I argue that in modern research, it is certainly necessary to take a critical approach to individual statements and holistic assumptions that have grown around shamanism for decades.
\end{abstract}

Keywords: Siberian shamanism, Mircea Eliade, Andrzej Wierciński, Buryats

\section{Wprowadzenie}

Tytułowe pytanie odnosi się do znanego Heglowskiego sformułowania mówiącego, że sowa Minerwy wylatuje dopiero o zmierzchu, a dotyczącego przewidywań rozwoju zjawisk, które nie są jeszcze zakończone, oraz do „ludowej 
mądrości”, zgodnie z którą krzyk sowy wieszczy rychłą śmierć. Wątki te bywają zresztą kontaminowane, pojawianie się sowy Minerwy o zmierzchu interpretowane jest jako konstatacja mówiąca o tym, że nauka zaczyna się zajmować opisem zjawisk „zbyt późno”, to znaczy, gdy zupełniej już zanikły lub są w fazie schyłkowej.

W niniejszym opracowaniu odnoszę zakres tejże metafory do klasycznych naukowych opisów szamanizmu syberyjskiego traktowanego przez wielu naukowców (wśród których główne miejsce zajmuje Mircea Eliade, a na polskim gruncie Andrzej Wierciński) jako część zjawiska „uniwersalnego” dla historii religii ludzkości, a zarazem należącego jedynie do przeszłości. Według rozpowszechnionych od XIX wieku opinii szamanizm miał być jedną z pierwszych religii ludzkości (Nowicka, 2006; Barnard, 2006; Bowie, 2008). Miał on odchodzić w przeszłość wraz z przejściem do osiadłego trybu życia i odejściem od gospodarki opartej na myślistwie. Kolejną zmianą, która miała odpowiadać za zmierzch szamanizmu, jest zróżnicowanie społeczne, a przede wszystkim zróżnicowanie „ról zawodowych”, jakie w niezróżnicowanych społecznościach miał pełnić szaman. Szamanizm więc odchodzi w przeszłość, „umiera” dwukrotnie. Odchodzi w przeszłość wraz z przemianami „pierwotnych społeczeństw”, będąc zastępowany przez religie późniejsze, a więc - zgodnie z ewolucjonistycznymi schematami, które stoją za tego typu rozumowaniem - religie „wyższe”. Druga, tym razem pełna śmierć szamanizmu, który gdzieniegdzie mógł przetrwać w postaci „przeżytku kulturowego”, następuje wraz z procesami modernizacji tradycyjnych społeczeństw, a ostatnim dla niego ciosem było wprowadzenie ideologii komunistycznej w Związku Radzieckim, która była zarazem antyreligijna i „postępowa”, a więc zwalczała wszelkie przejawy „zabobonów i wstecznictwa” (Wasilewski, 1985). W przypadku prześladowań syberyjskich szamanów dochodził jeszcze „element klasowy”. Szamani byli traktowani jako kułacy, którzy bogacą się kosztem prostej, nieoświeconej ludności, stosując różne teatralne, magiczne triki. Zwycięska walka z szamanizmem została ogłoszona w oficjalnej ideologii. Zgodnie z obowiązującą w Związku Radzieckim wersją, jeśli nawet gdzieś przetrwały fragmenty szamanizmu, jeśli nawet gdzieś żyli „byli szamani”, to szamanizm jako religia, przynajmniej na Syberii, z pewnością zniknął (szerzej analizuję problem „śmierci szamanizmu” w ideologii okresu radzieckiego w: Połeć, 2017). W kontekście niniejszego tematu najważniejszym aspektem problemu jest to, że przez długie dziesięciolecia można było bez dostępu do syberyjskich realiów traktować szamanizm syberyjski jako zjawisko należące wyłącznie do przeszłości.

W momencie więc, gdy swoje dzieło pisał Eliade, później zaś Wierciński i wielu innych korzystających z podobnych materiałów badaczy, przyjąć można było, że ich opis jest „krzykiem sowy Minerwy” we wszystkich wskazanych powyżej znaczeniach; można go już w pełni opisać, gdyż w swojej pierwotnej formie jest zamkniętym rozdziałem, opis zaś szamanizmu jest zarazem jego epitafium. 
Dla jasności wywodu trzeba tutaj stwierdzić, że zarówno Eliade, jak i Wierciński ubolewają nad „śmiercią szamanizmu”, przy czym pierwszy z nich stara się go propagować jako „technikę ekstazy”, którą można uprawiać niezależnie od kultury pochodzenia i staje się „amerykańskim guru” dla rozwijającego się nurtu neoszamanizmu, zaś Wierciński twierdzi wręcz, że od czasów rewolucji neolitycznej ewolucja ludzkości skręciła na niewłaściwe tory i jedynie powrót na ścieżkę wyznaczaną przez szamanizm może nas uchronić od katastrofy.

Renesans religii etnicznych ludów Syberii po upadku Związku Radzieckiego sprawia jednak, że tak rozumiany krzyk sowy Minerwy wydaje się być przedwczesny, mówiąc zaś mniej metaforyczne, wydaje się, że konieczne jest przynajmniej powtórne przeanalizowanie koncepcji uniwersalnego szamanizmu rozumianego jako prastara, najstarsza religia ludzkości. Zadanie to wydaje się ważne nie tylko ze względu na to, że obraz szamanizmu ukształtowany na dawnej literaturze wciąż jest obecny w wielu opracowaniach o charakterze ogólnym, ale także ze względu na to, że te obecne w klasycznej literaturze modele szamanizmu oddziałują na postrzeganie współczesnego szamanizmu syberyjskiego, odradzającego się po upadku Związku Radzieckiego i coraz bardziej widocznego także w sferze publicznej.

Zjawiska badane przez pryzmat kategorii szamanizmu, ale określane również emicznie jako szamanizm, na terenie współczesnej Syberii nie tylko trwają, ale zdają się rozwijać. Oczywiście łatwo jest bronić tezy o śmierci szamanizmu, twierdząc, że współczesne przejawy szamanizmu nie mają nic wspólnego z „ówczesnym szamanizmem”, że należą one do „neoszamanizmu”, a więc są lokalnym przejawem tej samej tendencji, którą zauważa się w ramach cywilizacji euroamerykańskiej. Można wskazywać na to, że pojedyncze przejawy szamanizmu nie są tym samym, co dawny szamanizm, można też twierdzić, że dzisiejsi szamani nie są szamanami autentycznymi, a jedynie odgrywają swoją rolę, nie różniąc się zbytnio od tych ludzi, którzy „rekonstruują” historię i stają się rycerzami, samurajami czy też innymi postaciami z historii. Takie twierdzenia są jednak do utrzymania jedynie przy bardzo pobieżnym oglądzie sytuacji.

Zadekretowana w radzieckiej ideologii śmierć syberyjskiego szamanizmu nie była „śmiercią naturalną”. Nie mieliśmy tutaj do czynienia ze spontanicznym odejściem od dawnych praktyk religijnych, w wielu przypadkach nie mieliśmy nawet do czynienia z dobrowolnym nawróceniem na inne religie, takie jak prawosławie czy buddyzm. Śmierć szamanizmu była wynikiem prześladowań szamanów i wyznawców szamanizmu przez władze radzieckie. Już wcześniej, w epoce przedradzieckiej, nawrócenia na prawosławie czy też buddyzm często były wspomagane presją ekonomiczną, siłą, a przynajmniej swoistą socjotechniką (Belyaeva, 2009).

Zwolennikom tezy mówiącej, że współcześnie można zaobserwować jedynie przejawy neoszamanizmu, warto wskazać na to, że ludy syberyjskie, gdy tylko to było możliwe, po epoce komunizmu zaczęły powracać do swoich dawnych wierzeń, które - jak się z czasem okazywało - nie były aż tak skutecznie wytępione jak to 
przedstawiała komunistyczna propaganda. Częściej były one ukryte, kontynuowane w okrojonej formie, czasami zachowała się o nich jedynie pamięć, zazwyczaj jednak widoczna jest chęć powrotu do własnych, kulturowych korzeni, a powroty te nie są traktowane jako zabawa czy też hobby, ale bardzo serio, nawet tam, gdzie powrót do dawnych tradycji wiąże się z różnorodnymi przeciwnościami, i nawet tam, gdzie tradycja została rzeczywiście zerwana (Głowacka-Grajper, Nowicka i Połeć, 2013).

Można oczywiście w tym kontekście posłużyć się argumentem mówiącym, że szamanizm, który obserwujemy współcześnie na Syberii, nie jest takim samym szamanizmem, jaki znamy z klasycznych opracowań, że jest to zjawisko tak różne od tego, jakie spotykamy w „modelach szamanizmu”, że nie można tutaj mówić o szamanizmie. Moim zdaniem, nawet jeśli stwierdzilibyśmy takie różnice, jeśli współczesne przejawy szamanizmu różnią się znacząco od tego szamanizmu, który znamy od Eliadego, a przede wszystkim od źródeł, z których korzystał Eliade (a nawet tych, których nie mógł z braku dostępności wykorzystać), świadczy to tylko na korzyść tych przejawów szamanizmu, które nie są odtwarzane z etnograficznych zapisek, ale są zjawiskiem odpowiadającym wyobrażeniom tworzących go społeczności.

Na podstawie własnych doświadczeń z badań terenowych prowadzonych wśród Buriatów (w latach 2000, 2010, 2013, 2014 i 2019¹) proponuję refleksję nad użytecznością klasycznych modeli szamanizmu dla badań współczesnych religii etnicznych ludów tradycyjnie uważanych za szamanistyczne.

\section{Szamanizm Mircei Eliadego}

Nikt z pewnością nie zrobił tyle dla rozpowszechnienia wiedzy na temat szamanizmu, co Mircea Eliade ([1951]1994). Rozpropagował on w cywilizacji Zachodu nie tylko termin „szamanizm”, ale i upowszechnił pewien typ myślenia o szamanizmie, który nie tylko zaważył na tym, jak zjawisko to rozumiemy dzisiaj, ale i zbudował wizję, którą ochoczo podchwycili inni. Jego postrzeganie szamanizmu prowadzi współcześnie do wielu kontrowersji wśród badaczy (Atkinson, 1992; Kehoe, 2000; Hutton, 2007). Sposób myślenia Eliadego i jego koncepcja szamanizmu jest jednak bardzo rozpowszechniona i wykorzystywana przez wielu poważnych badaczy. Za przykład można podać pracę Andrzeja Szyjewskiego (2005) będącą

\footnotetext{
${ }^{1}$ Wyjazd z 2000 został sfinansowany z subsydium profesorskiego FNP prof. Ewy Nowickiej, zaś wyjazd z 2010 sfinansowany został z grantu MNiSW N N116 300038, Buriaci Zachodni między politykq odradzania kultur a asymilacjq, którego kierownikiem była dr hab. Małgorzata Głowacka-Grajper. Wyjazdy z 2013 i 2014 r. odbyły się w ramach grantu Między Rosjq, Mongoliq i Chinami. Buriaci wobec wyzwań XXI wieku. Grant finansowany przez NCN (kierownik: prof. Ewa Nowicka) nr: OPUS 2011/03/B/HS6/01671. Wyjazd z 2019 r. na tereny zamieszkałe przez Buriatów w Mongolii odbył się w ramach grantu NCN Miniatura 2 DEC-2018/02/X/HS6/01283.
} 
wprowadzeniem w problematykę szamanizmu. Wpływy Eliadego są w niej nad wyraz widoczne. $W$ tym ujęciu szamanizm jawi się jako zjawisko obecne w każdym czasie i na każdym zamieszkiwanym przez ludzi kontynencie. Ujęcie to można by nazwać globalnym, gdyby nie to, że Eliade proponuje dość wąską definicję szamanizmu, który ma się opierać przede wszystkim na transie i wędrówkach szamana w zaświaty. Do koncepcji Eliadego odwołuje się jednak wciąż wielu badaczy, w tym badacze terenowi (Jastrzębski, 2014; Wierucka, 2013).

Kluczowym kontekstem koncepcji szamanizmu Eliadego jest jego koncepcja historii religii, w ramach której zakłada on istnienie „dialektyki hierofanii”, którą definiuje jako „radykalne oddzielenie profanum i sacrum oraz wynikające stąd rozdarcie rzeczywistości” (Eliade, 1994, s. 4). Historii religii w rozumieniu Eliadego nie należy jednak mylić z historiografią religii, czyli tym, co rozumielibyśmy poprzez zestawienie terminów „historia” i „religia”. W koncepcji Eliadego historia religii nie zajmuje się chronologią faktów religijnych ani tym bardziej historią instytucji religijnych. Tym, co go interesuje, jest uchwycenie poprzez konkretne, historyczne manifestacje tego, co jest wspólne, uniwersalne w sacrum. Pisze on:

Historię religii uprawia się wtedy, gdy próbuje się badać fakty religijne jako takie, to znaczy w ich specyficznej płaszczyźnie manifestacji: ten specyficzny plan manifestacji zawsze jest historyczny, konkretny, egzystencjalny, nawet jeśli manifestujące się fakty religijne nie zawsze ani nie w pełni dają się sprowadzić do historii. Wszystkie hierofanie, od najbardziej elementarnych (na przykład manifestacja sacrum w danym drzewie czy kamieniu) po najbardziej złożone („wizja” nowej „formy boskiej” przez proroka czy założyciela religii) występują w konkrecie historycznym i są w pewien sposób uwarunkowane przez historię. Niemniej w najskromniejszej hierofanii ukazuje się „wieczne rozpoczynanie od nowa”, wieczny powrót chwili bezczasowej, pragnienie zniesienia historii, wymazania przeszłości, ponownego stworzenia świata (Eliade, 1994, s. 8).

W tej koncepcji faktu religijnego czas i miejsce nie mają znaczenia, gdyż fakt religijny, sacrum, hierofania mogą się manifestować zawsze i wszędzie i za każdym razem będą równie autentyczne. Eliadego interesuje to, co pierwotne dla faktu religijnego, ale nie w takim znaczeniu jak ewolucjonistów, dla których „pierwotne” oznacza historycznie pierwsze, nawet jeśli nie zalążkowe, to będące zalążkiem kolejnych etapów. U Eliadego pierwotne jest to, co gatunkowo właściwe człowiekowi. Widać to wyraźnie chociażby w sposobie argumentacji przeciw rozpowszechnionej kiedyś hipotezie mówiącej, że szamanizm został na Syberię „przyniesiony z południa”. Eliade dopuszczając wpływy zewnętrzne na szamanizm „Ałtajczyków”, twierdzi, że wpływy te nie wytworzyły „ideologii i rytuału wniebowstępowania”, a raczej zmodyfikowały to, co pierwotne. Pisze on jednak w tym kontekście nie o pierwotnych wierzeniach ludów Syberii, ale podaje własną interpretację:

[szamanizm - W.P.] jest zjawiskiem pierwotnym, to znaczy należy ono człowiekowi jako takiemu, w jego integralności, a nie jako bytowi historycznemu: dowodem są 
sny, halucynacje i wyobrażenia wstępowania, które spotykamy na całym świecie, poza wszelkim „uwarunkowaniem” historycznym czy innym (Eliade, 1994, s. 6).

Zjawisko pierwotne u Eliadego jest więc bliskie Durkheimowskiemu „elementarnemu”, choć zarazem odrzuca on Durkheimowską metodologię. Poszukiwanie pierwotnego, elementarnego przez poszukiwanie archaicznego, „historycznego” jest płonne i bezzasadne. Pierwotne jest to, co „uniwersalne”, występujące zawsze i wszędzie, a odpowiednią metodą badania dla „odgadnięcia sensu danego zjawiska” jest dążenie „do zrozumienia zjawiska dopiero po uprzednim należytym porównaniu go z tysiącami podobnych czy odmiennych zjawisk, po osadzeniu go wśród nich: a te tysiące zjawisk dzieli zarówno przestrzeń, jak i czas” (Eliade, 1994, s. 7). Nieco paradoksalnie więc historia religii u Eliadego jest programowo ahistoryczna. Program Eliadego nie jest również programem ,indukcyjnym”; z trudem jedynie można powiedzieć, że stara się on stworzyć „typ idealny” zjawiska religijnego, gdyż interesuje go ta właśnie reszta, która pozostaje po historycznym, naukowym wyjaśnieniu. Pisze, że wszystkich tych uniwersalnych zjawisk, które go interesują, „nie da się wytłumaczyć wyłącznie psychologicznie; zawsze pozostaje jakiś pierwiastek niepodlegający wyjaśnieniu i owo nie znane mi nieredukowalne odsłania być może prawdziwą sytuację człowieka w Kosmosie, sytuację, która - jak będziemy to niestrudzenie powtarzać - nie jest wyłącznie »historyczna «” (Eliade, 1994, s. 6). Przy takim programie i przy takich założeniach rzeczywiście można swobodniej podchodzić do chronologii i geografii badanych zjawisk, zarazem traktując ustalenia psychologii, socjologii, etnologii, a nawet historiografii i archeologii jako ustalenia nauk pomocniczych, które mają na celu jedynie dostarczyć materiał do rozważań i usunąć niektóre problemy techniczne analizy. Problem pojawia się dopiero w momencie, gdy próbuje się korzystać z Eliadego, nie podzielając jego założeń. Problem stanowi też to, że często nie dostrzegając specyfiki zarówno założeń, jak i definicji Eliadego, ujmuje się jego koncepcję jako erudycyjne podsumowanie badań nad szamanizmem. Eliade z pewnością poszukuje „istoty szamanizmu", ale nie jako zjawiska historycznego (etnograficznego), ale jako zjawiska religijnego w jego własnym rozumieniu, chciałoby się powiedzieć - jako zjawiska hierofanicznego. Szamanizm z pewnością wspaniale nadaje się do celu Eliadego, ale jego koncepcja nie zawsze nadaje się do wykorzystania w badaniu szamanizmu.

Sugestywne opisy szamanizmu kształtują naszą zachodnią wyobraźnię, stając się, często mimowolnie, modelem dla zjawisk, jakie spotykamy „w terenie”, stają się one czasami również modelem dla tych członków społeczeństw szamanistycznych, którzy przejmując się „naukowymi” opisami szamanizmu, widzą rozbieżności między opisem a obserwacją i rozbieżności te interpretują na niekorzyść współcześnie działających szamanów. Podczas badań wielokrotnie spotkaliśmy się z tego typu sytuacjami, gdy szukaliśmy kontaktu z miejscowymi szamanami. Ludzie, których pytaliśmy o to, czy w danej miejscowości działa szaman, często 
mówili, że wprawdzie jest tutaj „ktoś taki jak szaman”, ale zarazem stwierdzali, iż nie jest to właściwie taki prawdziwy szaman, tylko ktoś, kto wchodzi w kontakt z duchami - jest jasnowidzem lub znachorem. Najczęściej w kontakcie z taką osobą okazywało się, że ta osoba ,jest szamanem”, o ile można pokusić się o tego typu stwierdzenia, to znaczy o zewnętrzne wyznaczanie granicy między tym, kto szamanem jest, a kto nim nie jest.

Dla Eliadego „test na szamana” jest prosty. Jeśli dana osoba odbywa „lot szamański”, jest szamanem, jeśli ten motyw się nie pojawia, jeśli dana osoba nie wchodzi w trans i w tym transie nie odbywa lotu do innego świata, to szamanem nie jest. Cóż jednak zrobić z typowymi dla buriackiego szamanizmu sytuacjami, w których to podczas transu w ciało szamana wchodzi duch przodka i przemawia jego ustami, ale swoim głosem? Według klasycznych, Eliadowskich kategorii to nie jest już szamanizm, ale kult opętania. Rację wydaje się mieć współczesny francuski badacz Bertrand Hell (1999), który uważa to rozróżnienie za błędne, gdyż „wylewa ono dziecko z kąpielą”. W ramach tego samego systemu wierzeń raz możemy mówić o „prawdziwym szamanizmie”, raz o „kulcie opętania”. Oczywiście można podsumować buriacki szamanizm jako niearktyczny, a więc z definicji niemodelowy, a wszelkie „skażenia” interpretować jako zewnętrzne wpływy. Nawet jednak w szamanizmie arktycznym, w ramach tej samej kultury i to w „klasycznym”, przedrewolucyjnym szamanizmie koegzystowały różne szamańskie tradycje, co na przykładzie Czukczów szczegółowo analizuje Anna-Leena Siikala (Siikala i Hoppál, 1998).

Przyjrzyjmy się jednak następującej sytuacji. Na terenie Mongolii przeprowadzamy w 2014 r. wywiad z szamanką i jej mężem, którzy prowadzą małą jadłodajnię w niewielkiej miejscowości. Miejscowi, mongolscy Buriaci, są potomkami „uchodźców” przed władzą radziecką. W Mongolii, jak to pokazuje Manduhai Buyandelgeriyn (2007), buriacki szamanizm rozwijał się przynajmniej tak prężnie, jak po rosyjskiej stronie granicy. Pewną różnicą jest tutaj jednak to, że Buriaci w Mongolii mówią najczęściej już jedynie po mongolsku, a nie po buriacku. Są to języki bardzo podobne, przez mongolistów język buriacki uważany bywa jedynie za dialekt mongolskiego, niemniej jednak sami Buriaci mówią o znaczących różnicach między buriackim a mongolskim (chałchaskim). Mąż naszej szamanki mówi nam o tym, że gdy podczas transu w jego żonę wchodzi buriacki przodek, zaczyna ona mówić po buriacku i to w jego archaicznej formie, której nie rozumieją najczęściej świadkowie jej transu, stąd też wynika konieczność jego obecności podczas „seansów” żony w roli tłumacza. Czy można jednak znaleźć lepszy sposób, by propagować buriackie tradycje kulturowe? Na terenie Rosji, gdzie problemem jest brak znajomości buriackiego, a większość Buriatów posługuje się jedynie językiem rosyjskim, szamanizm staje się silnym bodźcem do nauki własnego, etnicznego języka (Połeć, 2018). 
Inna osoba, matka szamana, również służąca swojemu synowi jako asystentka-tłumaczka z języka buriackiego, opowiada o zachciankach duchów, które żądają potraw i napitków, jakie pamiętają z czasów swego życia i które denerwują się, gdy proponuje się im współczesnego, fabrycznego papierosa, a nie tytoń, jaki pamiętają z czasów swojego życia. Można oczywiście stwierdzić, że jest to nowa forma starych trików używanych przez szamanów dla uwiarygodnienia swoich spektakli. Nawet jeśli tak jest, nie zmienia to jednak tego, że są to takie same triki jak opisywane przed wiekami także w nieprzychylnej szamanom literaturze, a więc, paradoksalnie, można tutaj mówić o ciągłości tradycji szamanistycznej.

Tego typu sytuacje zdaniem Buriatów pokazują istotę szamanizmu. Jeśli położymy tutaj nacisk na to, że wejście w ciało szamana ducha człowieka żyjącego przed dziesiątkami czy też setkami lat jest przejawem hierofanii, to koncepcja Eliadego okaże się przydatna w interpretacji faktów podobnych do tych przywołanych powyżej. Dzięki Eliademu można w tych opisach dostrzec ten element kontaktu z sacrum, który uważał on za pierwotny i uniwersalny. Jeśli jednak skupimy się na szczególe, którym jest to, że to duch przychodzi do ciała szamana, a nie szaman odbywa wędrówkę w zaświaty, okaże się, że wbrew użyciu przez samych zainteresowanych słów „szaman” i „szamanizm” nie mamy do czynienia ze zjawiskiem, które mieściłoby się w definicji szamanizmu zaproponowanej przez naszego klasyka.

\section{Szamanizm Andrzeja Wiercińskiego}

Rozróżnienie, czy to szaman w transie odbywa lot w innej rzeczywistości, czy w czasie transu wchodzi w niego duch przodka, zmarłego szamana czy też jeszcze innej osoby, nie jest centralne w koncepcji szamanizmu opracowanej przez Andrzeja Wiercińskiego, autora Modelu postaci szamana będącego częścią jego szerszej koncepcji dotyczącej miejsca szamanizmu w rozwoju ludzkości przedstawionej w zbiorze Magia i religia (2010). Dla Wiercińskiego najważniejsze jest to, że w stanie transu szaman jest w „odmiennym stanie świadomości”, choć i on skupia się na tej koncepcji szamanizmu, która zakłada wędrówki szamana po innych światach, w tym wędrówki wywołane (wspomagane) różnego rodzaju substancjami psychoaktywnymi.

Przywołuję tutaj tę koncepcję chociażby ze względu na słowa Andrzeja Szyjewskiego, który we wstępie do nowego wydania pracy zbierającej dorobek Wiercińskiego pisze, że jest to książka „bestsellerowa” (Szyjewski, 2010), a więc mająca potencjalnie szerokie oddziaływanie. Zarazem odnosząc się do osoby samego autora, Szyjewski przedstawia go jako „polskiego fundatora jeśli nie samej dyscypliny, jaką jest antropologia religii, to przynajmniej jej nazwy” (Szyjewski, 2010, s. VII). Dyscyplina ta rozumiana jest przez niego jako „zastosowanie an- 
tropologii ogólnej do religioznawstwa”. Zaraz potem Szyjewski doprecyzowuje, pisząc, że „Antropologia religii traktuje religię jako właściwy człowiekowi na poziomie gatunkowym system (osobliwość człowieka), w którym człowiek jest produktem biokulturowej adaptacji; bada sposób podzielania przekonań religijnych w społeczeństwach, ich kulturową i biologiczną podstawę”. Mamy więc tutaj do czynienia z szerokim i poważnym projektem, w którym szamanizm, jak zobaczymy niżej, odgrywa ważną rolę. Rysami charakterystycznymi „antropologii religii” Wiercińskiego, według Szyjewskiego, są nacisk na biologiczne uwarunkowania człowieka, koncepcja „małpoluda”, to znaczy dwoistości natury człowieka, oraz nacisk kładziony na analizy systemowe i miejsce człowieka w „biosferze”. Szyjewski podsumowuje założenia teoretyczne, z których wywodzi się teoria szamanizmu Wiercińskiego, w następujący sposób:

Podstawą zastosowania podejścia systemowego w humanistyce jest uznanie człowieka za system autonomiczny, a więc taki, który nie tylko reaguje na zmiany środowiskowe, ale potrafi też przeciwdziałać utracie zdolności do reagowania. Jego działania oparte są na sprzężeniu zwrotnym. [...] Najistotniejszym elementem systemu ludzkiego jest mózg, działający w funkcji korelatora (organu do przetwarzania i przechowywania informacji) $\mathrm{i}$ homeostatu, koordynującego przepływ informacji i energii tak, by działały na rzecz zachowania systemu. W korelatorze zachodzą procesy poznawcze i decyzyjne, których sprzęgnięcie pozwala wyłączyć automatyzm reakcji narzucany przez środowisko i program genetyczny (Szyjewski, 2010, s. XIV-XV).

Bez uprzytomnienia sobie powyższych założeń trudno jest zrozumieć i spojrzeć bezstronnie na założenia Wiercińskiego dotyczące szamanizmu. Najważniejszymi założeniami „podejścia systemowego” są: a) wyjaśnienie danego działania ludzkiego możliwe jest poprzez wskazanie czynników środowiskowych, w jakich ono następuje (a przynajmniej się ukształtowało), b) podstawą analizy działania ludzkiego jest analiza działania mózgu, który to c) mózg może osiągnąć pewien stopień niezależności (autonomii) działania od czynników środowiskowych. Całość więc rozumowania sprowadza się tutaj do działalności mózgu, który może być rozumiany bądź to jako korelator, gdy reaguje na zmiany środowiskowe, bądź to jako homeostat, gdy im nie odpowiada. W każdym z tych przypadków odpowiedź kryje się w ludzkim mózgu i jego niezwykłym rozwoju.

Kolejnym, bardzo ciekawym, punktem tej koncepcji jest założenie mówiące o dwoistości natury człowieka, wyrażające się, wedle słów Wiercińskiego, w tym, że:

Osobliwość natury gatunkowej człowieka zasadza się na jego polaryzacji na psychocielesną stronę zwierzęca, niejako ewolucyjnie „gotową” i psychomózgowy potencjał człowieczeństwa, którego „rozpływ” (realizacja) modyfikuje stronę zwierzęcą” (Wierciński, 2010, s. 20). 
W istocie więc człowiek jest „małpoludem”, którego potencjał człowieczeństwa może się potencjalnie rozwinąć w rozwoju osobniczym, a także w społeczno-kulturowym, nie jest zaś „dany” przez nasze dziedzictwo biologiczne. Jak wyjaśnia Szyjewski: „Punktem wyjścia dla rozumienia natury ludzkiej jest powstałe w konsekwencji zwiększenia wielkości mózgu charakterystyczne tylko dla człowieka zdwojenie świadomości typu refleksyjnego. O ile zwykłą świadomość, charakteryzowaną jako poczucie zewnętrznego świata i własnych manipulacji na jego elementach (bezpośrednie zdawanie sobie sprawy z przedmiotów, zdarzeń, relacji), mogą dysponować zwierzęta, to świadomość refleksyjna, wyznaczona przez świadomość własnej świadomości (możliwość myślenia o samym sobie jako o podmiocie działań, wejścia w rolę obserwatora zdarzeń życiowych) właściwa jest wyłącznie człowiekowi. W świadomości dokonują się skojarzenia, refleksja i wolicjonalna ocena. Dzięki niej człowiek może oderwać się od wykonywanej przez siebie czynności, może wreszcie swoje działania poddawać kontroli woli. We względnej wolności człowieka od determinującego wpływu programów genetycznych i kulturowych widzi Wierciński istotę odrębności człowieka od pozostałych zwierząt” (Szyjewski, 2010, s. XIX-XX). Przy takich założeniach rzeczywiście można przyjąć, że „człowieczeństwo nie jest nam dane na stałe, lecz może się realizować bądź nie”. Wierciński, stając się filozofem, zakłada oczywiście pozytywne wartościowanie „człowieczeństwa”, „wolności człowieka”. Normatywny charakter tej koncepcji staje się jeszcze wyraźniejszy w świetle kolejnego założenia koncepcji Wiercińskiego, które, na pierwszy rzut oka będąc jedynie logiczną konsekwencją założeń wcześniejszych, mówi o tym, że człowiek ma dwa środowiska, z których pierwszym jest środowisko zewnętrzne, a więc otoczenie człowieka, drugim zaś jest środowisko wewnętrzne, czyli własny organizm człowieka i jego zwierzęca psychika, na które to dopiero ma być nadbudowany „potencjał człowieczeństwa”.

Przedostatnim krokiem do koncepcji szamanizmu Wiercińskiego jest założenie mówiące o dwóch strategiach przetrwania wywodzące się z założenia o dwóch środowiskach człowieka. Wspólnym ich mianownikiem jest przekształcenie odpowiednio zewnętrznego i wewnętrznego środowiska człowieka. Na tym etapie rozumowania zapominamy o możliwości przystosowania się do danego środowiska, pozostają jedynie jego zmiany. Polegają one bądź to na przekształcaniu świata zewnętrznego za pomocą wypracowanego kulturowo wyposażenia technicznego, bądź to „przekształcenie swego ciała i psychiki w ten sposób, że potencjał może okiełznać biologiczne funkcje organizmu, przekształcając go w narzędzie poznawcze, którym można eksplorować bogaty świat wewnętrzny” (Wierciński, 2010, s. 20), co jest możliwe dzięki przejściu „zmieniającej świadomość inicjacji”. „Inicjacja” zaś utożsamiana jest z „,szamanizmem”. Szyjewski pisze:

Warto zwrócić uwagę na konieczność wprowadzenia religijnego IPS w nowe pokolenie nosicieli kultury, co dokonuje się z jednej strony automatycznie, poprzez procesy socjalizacji, z drugiej - kulminuje się przez przejście procedury inicjacji. Inicjację uważał 
Wierciński za potężny instrument umożliwiający realizację potencjału człowieczeństwa poprzez zapewnienie narzędzi eksploracji środowiska wewnętrznego - stanów transowych. [...] Inaczej mówiąc, prawidłowo skonstruowany system religijny powinien umożliwiać swoim wyznawcom przekraczanie zwykłego wymiaru świadomości i wkraczanie do rzeczywistości „wyższego” poziomu, co pozwala traktować „zwykłą rzeczywistość” jako iluzoryczną przykrywkę. Jak mówił na wykładzie, „wizje są naturalną potrzebą, nawet renifery zjadają (w tym celu) muchomory” (Wierciński, 2010, s. XXIII).

Nie mając szczęścia uczęszczania na wykłady prof. Wiercińskiego, trudno jest mi określić, w jakim kontekście pojawiła się tam ostatnia część cytatu, niemniej jednak w kontekście całościowej koncepcji „realizacji potencjału człowieczeństwa” uwaga na temat muchomorów zjadanych przez renifery wydaje się być dziwna. Jest ona zrozumiała jako chwyt retoryczny mający przekonać o „naturalności” spożywania substancji psychotropowych, ale nie jest zrozumiała w kontekście wyjątkowości cech człowieka i jego „eksploracji środowiska wewnętrznego”, gdyż bądź to sugerowałaby ona, że również renifery posiadają takie środowisko wewnętrzne i dodatkowo są one w stanie refleksyjnie nim manipulować, co niestety znosiłoby argument o wyjątkowości tej cechy u człowieka, bądź to posługiwanie się muchomorami i innymi substancjami psychotropowymi należałoby interpretować inaczej niż narzędzie „eksploracji środowiska wewnętrznego”.

Nie to jest jednak najważniejsze w kontekście syberyjskiego szamanizmu. Po pierwsze, stymulowanie się szamana środkami psychoaktywnymi nie zawsze i nie wszędzie ma miejsce, a w niektórych regionach jest wręcz traktowane jako słabość szamana (Hoppál, 2009). Po drugie, trzeba by bliżej przeanalizować sposób działania poszczególnych środków psychoaktywnych. Te dwa elementy są jedynie szczegółami wobec problemu, który w koncepcji Wiercińskiego jest podobny do analizowanego powyżej problemu z definicją szamanizmu Eliadego. Otóż szaman przyjmujący do swego ciała ducha w czasie transu raczej pozbywa się swojej świadomości niż ją rozszerza. Typową konsekwencją przyjęcia ducha bądź duchów przez szamana jest to, że po „wyjściu z transu” szaman nic nie pamięta z tego, co się działo, gdy przyjmował ducha, bo to nie on działał, lecz duch. Buriaci podkreślają, że nawet jeśli podczas transu szaman pił wódkę, to po jego zakończeniu jest trzeźwy, bo to duch spożył alkohol, a nie szaman. Kolejny więc raz pojawia się trudność uzgodnienia tego rodzaju koncepcji szamanizmu z niektórymi przynajmniej formami szamanizmu.

Wierciński umiejscawia szamanizm bezpośrednio w społecznościach łowiecko-zbierackich. Poza specyfiką formy i umiejscowieniem w szerszym systemie teoretycznym opinia Wiercińskiego nie różni się tu od klasycznych opisów miejsca „roli szamana” jako pierwszego stopnia jeszcze niezróżnicowanego zróżnicowania w społeczeństwach pierwotnych. Dowiadujemy się tutaj, że w każdym społeczeństwie muszą być jednostki, które będą nim kierowały, przy czym prawdopodobnie będą to jednostki, które są do tego najbardziej predystynowane pod względem cech 
charakterologicznych i posiadające dużą wiedzę. Specyfika stanowiska Wiercińskiego sprowadza się do wskazania źródeł wiedzy, która, według niego, musi być uzyskiwana w transie. Swoją drogą nie dowiadujemy się nic na temat sposobów, zakładanej tutaj, kontroli nad transem u szamanów. W innym miejscu Wierciński posługuje się (co w badaniach nad szamanizmem stało się już metodą standardową) badaniami nad osobami, którym podawano LSD. Dzięki tego typu badaniom dowiadujemy się, jakiego rodzaju wizje wywołują tego typu środki psychoaktywne, nie dowiadujemy się jednak nic na temat kontroli tego typu stanów.

Wierciński daje jednak kolejne założenia dotyczące konieczności pojawienia się szamanów w społecznościach ludzkich. Według niego powstanie szamanizmu można łączyć z uruchomieniem „potencjału człowieczeństwa” oraz ze zbieracko-łowieckim trybem życia człowieka. Pozostawiając na boku pierwszy argument jako „wewnątrzsystemowy” u Wiercińskiego, skupmy się na powiązaniu szamanizmu z gospodarką łowicko-zbieracką. Tutaj mamy dwa argumenty. Pierwszy mówi o konieczności specyficznego treningu o charakterze deprawacyjnym, niezbędnego dla sprawnego myśliwego, zwłaszcza w sytuacji zbiorowego polowania, drugi zaś łączy szamanizm ze zbieraniem roślin, które ma doprowadzić do znalezienia enteogenów (substancji psychotropowych). Pierwszy argument może zasadnie tłumaczyć powstawanie rytuałów inicjacyjnych na bazie treningu łowieckiego, choć wydaje się, że nie jest tutaj warunkiem koniecznym użycie środków halucynacyjnych, wręcz można by wskazać na to, że w przypadku „treningu łowieckiego” bardziej przystosowawcze byłoby się utrzymanie się świadomości „doczesności”. Dużo bardziej przekonująca jest w tym zakresie teoria francuskiej badaczki Robert Hamayon, która łącząc szamanizm ze społecznościami typu myśliwskiego, wskazuje na specyficzny system wierzeń, w którym szaman jest pośrednikiem między światem ludzi a światem przyrody (Hamayon, 1990). Argument drugi mówi jedynie o tym, że żeby móc używać środków psychotropowych, trzeba mieć do nich dostęp. Nic nie mówi jednak o tym, w jaki sposób, kto i dlaczego ich używa. W tym kontekście bardziej przekonujące, choć równie hipotetyczne mogą być teorie mówiące o tym, że techniki jogi powstały jako skutek braku dostępu do substancji psychoaktywnych (por. Tokarski, 1984). Moim zdaniem o ile można się zgodzić z założeniem, że szaman, podobnie jak każdy kapłan czy szerzej nawet autorytet, może mieć i często ma znaczący wpływ na kształtowanie opinii w swoim społeczeństwie, o tyle niekoniecznie trzeba wiązać ten wpływ z używaniem środków psychoaktywnych. Autorytet przekazu szamana mógł polegać na tym, że miał on bezpośredni kontakt z sacrum, z bóstwami i duchami i mógł twierdzić, że jest w stanie przekazać bezpośrednio ich wolę. Tak rozumiany szaman staje się (także u Wiercińskiego) prototypem proroka i każdego twórcy religii, chociaż zbytnim uproszczeniem jest opinia, że każdy szaman tworzy swoją odrębną religię. Etnograficzne badania szamanizmu pokazują, że ich działalność jest głęboko zakorzeniona w tradycji kulturowej ich ludu. Nawet gdyby przyjąć założenie, że szaman jest rodzajem 
przywódcy charyzmatycznego, to musi on zawsze być o tyle tradycyjny, o ile to, co mówi, musi odpowiadać kategoriom poznawczym tych, którzy mają go słuchać. Zupełnie zaś odrębną sprawą jest to, że szaman uwiarygadnia swoje twierdzenia przez różnorodne dowody kontaktu z sacrum, które zewnętrzny obserwator może oceniać jako „sztuczki” czy „triki”. W tak rozumianym emploi szamana trans jest jedynie jednym z nich. W tym kontekście pouczające są rozważania Claude’a Lévi-Straussa w jego Antropologii strukturalnej (2000). Hipoteza związku szamanizmu z myśliwstwem spotyka się jednak z innym jeszcze problemem, jakim jest różnica między „powszechnym” systemem inicjacji, a więc obejmującym przynajmniej wszystkich myśliwych w danej społeczności, a „elitarnym”, ,ekskluzywnym” systemem inicjacyjnym, ograniczonym jedynie do szamanów. Problem ten wymaga wprowadzenia „dwóch stadiów” szamanizmu. Jedynie w „pierwotnym stadium” inicjacja byłaby dostępna dla wszystkich (w tym dla kobiet). Wedle tej hipotezy więc szamanizm syberyjski nawet w swej klasycznej, przedrewolucyjnej formie byłby już zmienioną, „zdegenerowaną” formą.

Zgodnie z rozumowaniem Wiercińskiego od czasów społeczności łowiecko-zbierackich ewolucja człowieka skręca w stronę środowiska coraz bardziej „,antydeprywacyjnego”, co powoduje, mówiąc w skrócie, odejście od szamanizmu „egalitarnego” na rzecz szamanizmu „elit szamańskich”, a w dalszych konsekwencjach poprzez „deascetyzację” elit do powstania stanu kapłańskiego. Szaman pozostaje jedynie jako postać wzorcowa i wyjściowa dla innych postaci organizatorów życia religijnego - od mitycznego herosa kulturowego, poprzez świętego króla i proroka założyciela, a na mesjaszu skończywszy.

W ten sposób uzyskujemy założenie mówiące o tym, że szamanizm jest religią wytworzoną w społecznościach łowiecko-zbierackich i z nią strukturalnie złączoną poprzez osobę szamana, który w tym spekulatywnym modelu jest jednoosobowym przedstawicielem systemu religijnego. Wraz z rozwojem cywilizacji i zanikaniem warunków „deprywacyjnych” oraz wraz z rosnącym zróżnicowaniem społecznym zanikać będzie szamanizm. Zanikniecie warunków deprywacyjnych (i niewyjaśnione u Wiercińskiego zarzucenie używania środków halucynogennych) prowadzić będzie do zanikania „bezpośredniego kontaktu z sacrum”, zaś rosnące zróżnicowanie społeczne będzie odpowiadać za różnicowanie się ról społecznych, które skupiał w sobie szaman.

Z punktu widzenia takiej koncepcji szamanizmu poszukiwanie współcześnie szamanów powinno być z góry skazane na niepowodzenie nawet bez uwzględnienia polityki i działań Związku Radzieckiego w kierunku wyrugowania szamanizmu. Jeśli łączyć będziemy szamanizm z daną formą społeczeństwa, z danym systemem gospodarczym, zmiana w społeczeństwie może implikować zmiany czy też zanik szamanizmu. Jeśli nie mamy do czynienia z niezróżnicowanymi wewnętrznie ludami łowiecko-zbierackie żyjącymi w niesprzyjających, deprywacyjnych warunkach środowiskowych, używanie w stosunku do ich systemu wierzeń terminu 
„szamanizm” musi się wydawać w koncepcjach takich jak Wiercińskiego nieporozumieniem. Przy takim założeniu szamanizm musi po prostu być zjawiskiem zupełnie innym niż to zjawisko, jakie można obserwować współcześnie w postaci etnicznych religii rdzennych ludów Syberii czy też innych obszarów, a tego nigdy nie udowodniono i nie próbowano na poważnie udowodnić, gdyż problem uważano za rozwiązany w klasycznych opisach szamanizmu bądź nierozwiązywalny z powodu braku dostępu do danych. Takie uproszczenia są jeszcze łatwiejsze wtedy, gdy nie będziemy rozdzielać warunków powstawania danego zjawiska od warunków trwania i rozwoju tego zjawiska. Przy założeniu zaś braku dostępu do obserwacji wydawać się mogło, że daleko idące spekulacje są uprawnione.

W ostatnich dziesięcioleciach sytuacja zmienia się diametralnie. Po upadku Związku Radzieckiego badacze z zewnątrz mają nie tylko większy dostęp do terenów, które przez dziesięciolecia były dla nich zamknięte lub przynajmniej restrykcyjnie strzeżone (Balzer, 2011; Humphrey, 2010). W tym samym okresie dochodzi do renesansu praktyk szamanistycznych na terenie Syberii w różnorodnych grupach etnicznych, które mają tradycje szamanistyczne czy też były w przedrewolucyjnych czasach opisywane jako mające tradycje szamańskie. Renesans dawnych wierzeń nie zawsze odbywa się pod szyldem szamanizmu. Niektóre grupy i środowiska programowo odżegnują się od tego obcego określenia, rozwijając jednocześnie praktyki religijne, które w kolonialnych opisach były określane jako szamanistyczne.

Oczywiście również wśród samych badanych przez mnie Buriatów można dostrzec tendencję do interpretowania swojego etnicznego systemu wierzeń w kategoriach innych niż szamanizm. Przewodniczący działającego w Ułan Ude centrum szamanistycznego „Tengeri” mówi nam w wywiadzie, że posługuje się on terminem szamanizm tylko z tego powodu, by być zrozumianym przez rosyjskojęzyczną, czy też szerzej „zachodnią” większość, prawidłową zaś nazwą wyznawanej i reprezentowanej przez niego religii jest tengrianizm, czyli starożytna religia Mongołów, wyznawana również przez Czyngis-chana. Podobnie przedstawia sytuację współczesny buriacki uczony Nikolaj Abajew (Абаев, 2014), który w swoich publikacjach przedstawia tengrianizm jako religię „,cywilizacji stepowej”. Ścisłe powiązanie „szamanizmu” z tradycyjnym trybem życia Buriatów widoczne jest również w pracach innych szamanów, którzy nie rezygnują z używania terminu szamanizm, a zarazem głoszą tezę, że szamanizm jest pierwotną religią całej ludzkości (Гомбоев, 2010; Хагдаев, 1998). W kontaktach między szamanami i zewnętrznymi obserwatorami, badaczami szamanizmu, można zauważyć niekiedy napięcie wynikające z tego, że zewnętrzny obserwator przyjeżdża z już gotową, choć nie zawsze w pełni uświadomioną wizją szamanizmu ukształtowaną na podstawie erudycyjnych, klasycznych jego opisów. W takich sytuacjach szamani nie tyle muszą tłumaczyć, czym szamanizm jest, bo obserwatorom wydaje się, że świetnie to wiedzą, ale czym szamanizm nie jest. 


\section{Podsumowanie. Niepewność sowy Minerwy}

Próbując podsumować rozważania nad użytecznością klasycznych modeli szamanizmu dla badań współczesnych religii etnicznych ludów tradycyjnie uważanych za szamanistyczne, można zauważyć, że niewątpliwą ich zaletą jest zarysowanie samego problemu szamanizmu, wskazanie na interesujące zjawisko i potencjalne korzyści dla naszej wiedzy naukowej z badań nad tym zjawiskiem. Z pewnością wielu badaczy zainteresowało się zagadnieniami związanymi z szamanizmem właśnie dzięki sugestywnym opisom klasyków. Klasyczne modele szamanizmu są więc użyteczne jako swobodna rama intelektualnej inspiracji. Ich użyteczność zmniejsza się skokowo, gdy będziemy traktować je jako „krzyk sowy Minerwy”, a więc podsumowanie wiedzy na temat podejmowanego zagadnienia. W tym rozumieniu krzyk ten wydaje się przedwczesny, gdyż szamanizm nie tylko nie jest zjawiskiem należącym do przeszłości, ale nie jest też zjawiskiem niemożliwym do zbadania. We współczesnych badania z pewnością konieczne jest krytyczne podejście do poszczególnych twierdzeń i całościowych założeń, które przez dziesięciolecia narosły wokół szamanizmu, konieczne jest również zastosowanie nowych metod analizy i zbierania danych. Szamanizmem interesują się przedstawiciele wielu dyscyplin naukowych, gdyż wiedza o nim może być pomocna w rozwiązywaniu różnorodnych problemów kluczowych dla tych dyscyplin. Ta wielość podejść czasami nie ułatwia zadania badaczom, którzy muszą brać pod uwagę specyfikę poszczególnych dyscyplin, ale też różnorodność pytań badawczych, kluczowych dla poszczególnych podejść. Jeśli krzyk sowy Minerwy zinterpretowalibyśmy jako wskazanie ważkości problemu naukowego, okazuje się, że nie jest on przedwczesny, a przy okazji nie jest jeszcze wystarczająco słyszalny. Problematyka szamanizmu jest wciąż otwartym, interdyscyplinarnym polem badawczym, na którym możliwe są znaczące i ciekawe odkrycia. Dobrym przykładem mogą tutaj być badania archeologów, takich jak prof. Andrzej Rozwadowski. Problematyka szamanizmu od długiego już czasu jest ważna ze względu na sposoby interpretacji sztuki naskalnej. Prace Rozwadowskiego pokazują, jak odmienne i twórcze rezultaty można uzyskać, podchodząc krytycznie do zastanych koncepcji i realizując własne badania (Rozwadowski, 2009). Pokazują również, jak dużo potrafi wnieść współpraca między różnymi dyscyplinami (Grzelczyk i Rozwadowski, 2017).

Badania antropologiczne zawieszają najczęściej pytania, które są najważniejsze dla badań archeologicznych, ale także często korzystają z modeli szamanizmu ukształtowanych przez klasyków. W ostatnich dziesięcioleciach widoczna jest nie tylko intensyfikacja badań terenowych nad różnego rodzaju przejawami szamanizmu, ale także wzmożona dyskusja nad aparatem pojęciowym i założeniami teoretycznymi, jakie stosuje się do opisu szamanizmu. Jednym z kamieni milowych była praca Atkinson podsumowująca dotychczasowe sposoby rozumienia szamani- 
zmu (Atkinson, 1992). W późniejszym okresie prac krytycznie, a czasami bardzo krytycznie (Kehoe, 2000), podchodzących do klasycznego modelu szamanizmu i jego europejskiej recepcji pojawiło się więcej (Boekhoven, 2011). Badacze coraz częściej próbują wypracować nowe kategorie analizy (Bumochir, 2014) czy też zaproponować własne podsumowanie spojrzenia na szamanizm (Hamayon, 2015). Widoczne jest zadawanie nowych pytań odnośnie do szamanizmu funkcjonującego we współczesnych społeczeństwach (Buyandelger, 2013; Połeć, 2018). Widoczne są także dyskusje dotyczące problemów użycia samego terminu szamanizm i wpływy „zachodniej wyobraźni” na postrzeganie innych kultur (Rydving, 2011; Hutton, 2007; Znamenski, 2007).

Analiza różnorodnych współczesnych przejawów szamanizmu oraz literatury naukowej dotyczącej szamanizmu pozwala z pewnością na stwierdzenie, iż obecnie daleko jesteśmy od zmierzchu szamanizmu. Można zaś mówić o jego renesansie i renesansie zainteresowania szamanizmem przedstawicieli różnorodnych dyscyplin naukowych.

\section{Literatura}

Atkinson Jane Monnig (1992). Shamanisms Today. Annual Review of Anthropology, Vol. 21, 307-330.

Balzer Marjolie Mandelstam (2011). Shamans, Spirituality, and Cultural Revitalization. Explorations in Siberia and Beyond. New York: Palgrave Macmillan.

Barnard Alan (2006). Antropologia. Warszawa: PIW.

Belyaeva Veronika (2009). Szamani i lamowie w sercu Sajanów: współczesny system wierzeniowy Buriatów Doliny Tunkijskiej. Wrocław - Poznań: Polskie Towarzystwo Ludoznawcze.

Boekhoven Jeroen W. (2011). Genealogies of Shamanism: Struggles for Power, Charisma and Authority. s.l.: Barkhuis.

Bowie Fiona (2008). Antropologia religii. Wprowadzenie. Tłumaczenie Kamila Pawluś. Kraków: Wydawnictwo Uniwersytetu Jagiellońskiego.

Bumochir Dulam (2014). Institutionalization of Mongolian shamanism: from primitivism to civilization. Asian Ethnicity, 15(4), 473-491.

Buyandelger Manduhai (2013). Tragic Spirits: Shamanism, Memory, and Gender in Contemporary Mongolia. Chicago: University of Chicago Press.

Buyandelgeriyn Manduhai (2007). Dealing with uncertainty: Shamans, marginal capitalism, and the remaking of history in postsocialist Mongolia. American Ethnologist February, Vol. 34(1), 127-147.

Eliade Mircea (1994). Szamanizm i archaiczne techniki ekstazy. Warszawa: Wydawnictwo Naukowe PWN.

Głowacka-Grajper Małgorzata, Nowicka Ewa, Połeć Wojciech (2013). Szamani i nauczyciele. Przemiany kultury Buriatów zachodnich. Warszawa: Wydawnictwa Uniwersytetu Warszawskiego. 
Grzelczyk Maciej, Rozwadowski Andrzej (2017). Sztuka naskalna regionu Kondoa w Tanzanii. Gdzie archeologia spotyka się z etnologiq. W: Andrzej Rozwadowski (red.), Sztuka naskalna - polskie doświadczenia badawcze. Warszawa - Toruń: Tako.

Hamayon Roberte (2015). Le chamanisme. Fondements et pratiques d'une forme religieuse d'hier et aujourd'hui. Paris: Eyrolles.

Hamayon Roberte (1990). La Chasse à l'âme : Esquisse d'une théorie du chamanisme sibérien. Nanterre: Société d'ethnologie.

Hell Bertrand (1999). Possession et chamanisme. Les maîtres du désordre. Paris: Flammarion.

Hoppál Mihály (2009). Szamani euroazatyccy. Warszawa: Iskry.

Humphrey Caroline (2010). Koniec radzieckiego życia. Ekonomie życia codziennego po socjalizmie. Tłumaczenie Agnieszka Halemba. Kęty: Wydawnictwo Marek Derewiecki.

Hutton, Ronald (2007). Shamans: Siberian Spirituality and the Western Imagination. London - New York: Continuum International Publishing Group.

Jastrzębski Bartosz (2014). Współcześni szamani buriaccy w przestrzeni miejskiej Ułan Ude. Wrocław: Wydawnictwo Uniwersytetu Wrocławskiego.

Kehoe Alice Beck (2000). Shamans and Religion. An Anthropological Exploration in Critical Thinking. Long Grove: Waveland Press.

Lévi-Strauss Claude (2000). Antropologia strukturalna. Warszawa: Wydawnictwo KR.

Nowicka Ewa (2006). Świat człowieka - świat kultury. Warszawa: Wydawnictwo Naukowe PWN.

Połeć Wojciech (2017). Czy postsocjalizm wytworzy „postszamanizm”? O problemach badań współczesnego syberyjskiego szamanizmu. Prace Etnograficzne 45(4), 429-442.

Połeć Wojciech (2018). Tajemny język szamanów? Przemiany funkcji języka buriackiego u Buriatów zamieszkujących w Rosji. W: Anna Landau-Czajka (red.), Systemowe uwarunkowania języka i komunikacji społecznej. Warszawa: Wydawnictwo SGGW.

Połeć Wojciech (2018). Shamanism and Cultural Reflexivity. Societas/Communitas, 1-1 (25-1), 51-73.

Rozwadowski Andrzej (2009). Obrazy z przeszłości. Hermeneutyka sztuki naskalnej. Poznań: Wydawnictwo Naukowe UAM, 2009.

Rydving Håkan (2011). Le chamanisme aujourd'hui : constructions et déconstructions d'une illusion scientifique. Études mongoles et sibériennes, centrasiatiques et tibétaines, 42.

Siikala Anna-Leena, Hoppál Mihály (1998). Studies on Shamanism. Helsinki - Budapest: Finish Anthropological Society, Akadémiai Kiadó.

Szyjewski Andrzej (2010). “Miara, liczba i waga” - Andrzeja Wiercińskiego droga do poznania. W: Andrzej Wierciński, Magia i religia. Szkice z antropologii religii. Kraków: Zakład Wydawniczy Nomos, VII-XXX.

Szyjewski Andrzej (2005). Szamanizm. Kraków: Wydawnictwo WAM.

Tokarski Stanisław (1984). Eliade i Orient. Wrocław - Warszawa - Kraków - Gdańsk Łódź: Zakład Narodowy imienia Ossolińskich, Wydawnictwo Polskiej Akademii Nauk.

Wasilewski Jerzy Sławomir (1985). Podróże do piekieł. Rzecz o szamańskich misteriach. Warszawa: Ludowa Spółdzielnia Wydawnicza, 1985.

Wierciński Andrzej (2010). Magia i religia. Szkice z antropologii religii. Kraków: Zakład Wydawniczy Nomos.

Wierucka Aleksandra (2013). Modern forms of Buryat shaman activity on the Olkhon Island. Anthropological Notebooks, Vol. 19(3), 101-119. 
Znamenski Andrei A. (2007). The Beauty of the Primitive. Shamanism and the Western Imagination. New York: Oxford University Press.

Абаев Николай В. (2014). Тэнгрианский культ священных гор и героический эпос монголо-бурят. Улан-Удэ: «Багульник», BSGroups Ltd.

Гомбоев Содном Жигмитдоржиевич (2010). Под вечным синим небом. Святая неугасимая вера. Шаманизм. Улан-Удэ: НоваПринт.

Хагдаев Валентин В. (1998). Шаманизм и мировые религии. Иркутск: Изд. ГП «Иркутская обл. тип. 